\title{
SAVINGS ASSOCIATIONS AS LAND DEVELOPERS
}

\author{
GEORGE LEFCOE*
}

THOMAS W. DOBSON†

THE stereotyped American housing development-unsightly, unimaginative and inefficient-is the usual work of small, undercapitalized builders. Their scale of operations prevents them from creating planned communities or new towns which offer neighborhood parks, planned school sites, and other such amenities. 1

The small developer's lifeline is the savings and loan association.? This is where he obtains funds for real estate projects that are too small and too risky to raise even an investigation from most banks and life insurance companies. Savings associations survive by paying a higher rate of interest than banks, and they need the extra margin that small builders are willing to pay to finance their speculative ventures. ${ }^{3}$

* Professor of Law, University of Southern California; Visiting Professor of Law. Yale University, Fall Term, 1966. A.B. 1959, Dartmouth College; LL.B. 1952, Yale University. I wish to thank the Walter E. Mejer Research Institute of Law for its financial support of the research necessary for this paper. Many of my colleagues at the University of Southern California have provided useful guidance and criticism, and I wish especially to thank William R. Bishin, Howard B. Miller, and Lconard G. Ratner.

$\dagger$ Editor-in-chief, University of Southern California Law Revicw, 1966-67.

1. "The largest developments are able to provide a complete set of community facilities, including a shopping center, as an integrated part of the whole. In the Levittowns, even schools have been built by the developer at no cost to the municipality. Developments of several hundred houses still can offer some common facilitics such as play:grounds, a disposal system, or a group of local stores. By contrast, the only community facility a small subdivision of 10 to 50 houses can offer is a new street-a loop or cul-de-sac, and still smaller groups as well as individual houses locate as a rule on an existing road, which, quite often, ought not to be permitted to become a residential street, both in consideration of the resident's safety and of traflic capacity." TunNaro \& Pushrarev, Man-Made America: Chaos or Control? 79 (1963).

2. Cf. Grebler \&. Brighant, Savings and Mortcage Mlarkets in Califoriila 52.61 (1963); Herzog, The Dynamics of Large-Scale Housebunding 33-56 (Institute of Business and Economic Research, University of California, Berkeley, Rescarch Report 22, 1963). California statistics are particularly important; savings and loan assets in California are the largest in the nation-over $\$ 23$ billion. Illinois follows with $\$ 10$ billion, Ohio with $\$ 9$ billion, and New York with $\$ 7$ billion. United States Savinas and Loan Leacue, Savics AND LOAN FACT BOOK 81 (1965) [hereinafter cited as 1965 FACr BOOK].

3. The Federal Home Loan Bank Board (FHLBB) series showing home mortgage interest rates and terms for conventional first mortgage loans currently made by type of institution reveals the following for December, 1964: 
Of course, mortgage loans are not the only source of high-yield real estate investment opportunities. Better rates of return would be available to savings associations if they invested directly in large-scale, planned real estate developments. ${ }^{4}$ But the associations are regulated by outdated laws that impose strict separation of the investment and

\begin{tabular}{|c|c|c|c|c|c|}
\hline \multicolumn{6}{|c|}{ PuRchase of New Single Family Homes } \\
\hline & $\begin{array}{l}\text { nterest Rate } \\
\text { (per cent) }\end{array}$ & $\begin{array}{c}\text { Fees, Charges } \\
\text { (per cent) }\end{array}$ & $\begin{array}{c}\text { Term of } \\
\text { Contract } \\
\text { (years) }\end{array}$ & $\begin{array}{l}\text { Loan to Price } \\
\text { (per cent) }\end{array}$ & $\begin{array}{c}\text { Purchase } \\
\text { Price } \\
\text { (thousands) }\end{array}$ \\
\hline All Lenders & 5.76 & 0.59 & 25.2 & 73.9 & 24.8 \\
\hline Savings \& Loan Assns. & 5.85 & 0.65 & 25.2 & 76.7 & 23.2 \\
\hline $\begin{array}{l}\text { Life Insurance } \\
\text { Companies }\end{array}$ & 5.53 & 0.20 & 26.8 & 68.5 & 28.8 \\
\hline $\begin{array}{l}\text { Mortgage } \\
\text { Companies }\end{array}$ & 5.72 & 0.91 & 27.1 & 74.4 & 25.2 \\
\hline $\begin{array}{l}\text { Commercial } \\
\text { Banks }\end{array}$ & 5.67 & 0.09 & 19.2 & 62.7 & 24.4 \\
\hline $\begin{array}{l}\text { Mutual Savings } \\
\text { Banks }\end{array}$ & 5.52 & 0.03 & 25.1 & 68.3 & 24.5 \\
\hline \multicolumn{6}{|c|}{ Purchase of Existing Single Family Homes } \\
\hline All Lenders & 5.92 & 0.56 & 20.1 & 71.7 & 19.2 \\
\hline Savings \& Loan Assns. & 6.02 & 0.73 & 20.9 & 74.6 & 18.0 \\
\hline $\begin{array}{l}\text { Life Insurance } \\
\text { Companies }\end{array}$ & 5.51 & 0.17 & 25.0 & 69.4 & 28.4 \\
\hline $\begin{array}{l}\text { Mortgage } \\
\text { Companies }\end{array}$ & 5.52 & 0.60 & 23.8 & 69.2 & 84.0 \\
\hline $\begin{array}{l}\text { Commercial } \\
\text { Banks }\end{array}$ & 5.30 & 0.16 & 15.8 & 63.3 & 20.0 \\
\hline $\begin{array}{l}\text { Mutual Savings } \\
\text { Banks }\end{array}$ & 5.58 & 0.18 & 21.9 & 69.6 & 21.0 \\
\hline
\end{tabular}

Source: FHLBB, 1965 Savings ANd Home Financing Source Book 20.21 (1965).

4. In the past decade, land in the United States has appreciated at the rate of $10 \%$ per annum. What about Real Estate as an Investment Now, U.S. News and World Report, June 20, 1966. In California, the average over a similar span lias been $18 \%$ per annum. Interview With Kent Williams, Property Research, Los Angeles, Calif., July 5 , 1966. Since 1956, yields on successful shopping centers have ranged from 8 to $15 \%$. Interview With Walter Clark, Senior Loan Officer, Security First National Bank, Los Angeles, Calif., Aug. 14, 1966. There are no collected figures on returns on large-scalc planned communities. However, a recent study by the National Association of Homc Builders (NAHB) indicates that the average builder receives $8 \%$ to $10 \%$. Interview with John Malone, Homebuilders Association (Los Angeles affliate of NAHB), Los Angeles, Calif., Sept. 7, 1966. With scale economies, this percentage tends to rise. HiErzoc, op. cit. supra note 2 , at 22-27. 
development functions. Most states forbid savings associations to purchase and develop land, and in the few permissive states the investment is restricted to a small percentage of an association's total assets. ${ }^{\circ}$ If these restrictions were lifted, substantial funds could be diverted from haphazard, small-scale developments into sizeable, planned communities. Savings and loan associations, which account for nearly half the non-farm residential mortgage debt, could make a contribution as properly financed land developers.

\section{Diseconomles of Small-Scale and Undercaptralized Development}

The special villain of suburban housing development, the small, undercapitalized builder, usually develops small tracts that are difficult to blend into their natural settings. His site layout suffers as a result, for achieving harmony with the natural setting is a prime factor in site design. The beauty of hillside development, for example, may depend on whether roof lines echo the dominant slope of the ground, houses ascend the hill in regular steps, and streets follow the contours of the ground. Unless a single developer controls the entire vista an investment in site planning and architects' fees will be uneconomic should adjoining parcels be developed without a sense of taste, imagination, or order. ${ }^{7}$ For then buyers will regard the entire area as just another hillside. ${ }^{8}$ As the small or undercapitalized builder can rarely afford large parcels, he usually foregoes the expense of site planning in anticipation of unsightly development nearby.

By including mixed land uses-apartments and houses, shops and

5. Alaska Stat. ANN. § 06.30.615 (1962); Car. Fin. Code $\S$ 6705; Fla. Stats. ANi., § 665.21(8) (Supp. 1964); IDAFo CodE ANN., § 30-1304 (1948); IrL. REv. Stat. ch. 32, 799 (1957); Iowa Code ANN. § 534.17 (Supp. 1965); Mích. Stat. ANN. § 23.540 (382) (Supp. 1965); Mo. Stat. ANN. § 369.370 (1952); Nev. Rev. Stat. § 673.276 (1956); N.H. REv. Stat. ANN. § 393.24 (1955); N.M. STAT. ANN. § 48.15-5 (Supp. 1965); OKLA. Stat. ANN. § 233 (Supp. 1965); Wash. Rev. Code § 33.24.095. Pennsylvania, Illinois, Ohio, New Jersey, Maryland, and California account for more than half of the nation's savings associations, yet only two of these states allow land investment.

6. In a few of these states, such as Illinois, as much as ten per cent of an associntion's assets may be invested but five per cent is the usual cciling.

7. The spillover effects of land development are well described elsewhere. See, e.g., Mandelker, Controlling Land Palues in Areas of Rapid Urban Expansion, 12 U.C.L.A. L. REv. 734 (1965); Dagen \& Cody, Property, et al. v. Nuisance, et al., 26 LAv \& CoNTEur. PRoв. 70, 79-82 (1961).

8. There is little question that the amenity value of the site as perceived by prospective buyers is a determinant of land values. See Brigham, The Determinants of Residential Land Values, 41 Land Econ. 325, 328 (1965); HoYt, Drwasic Factors in LaNd Values 14-15 (U.L.I. Tech. Bull. No. 37, 1960). 
schools-large-scale development provides visual diversity, and satisfies a larger share of the housing market. ${ }^{\circ}$ By contrast, the small tract builder, hoping to sell quickly and avoid the cost of a careful market analysis, builds only for the largest sector of the housing marketyoung married couples with middle or higher incomes and two or three children. ${ }^{10}$ Unlike the large developers he runs no risk of saturating a sector of market; and in any case the size of his parcel precludes much variety in his houses or his clientele.

The developers of new towns and planned communities profit by forestalling strip commercial development in favor of graceful shopping plazas and malls; they know that pleasant shopping facilities augment the sale of housing in their projects. Shopping center developers who are unconcerned with adjacent housing, tend to disregard their impact on neighboring land.

The developer of a large project ordinarily dedicates more land for

9. A series of public hearings conducted by the Northeastern Illinois Planning Commission revealed that the most important planning goal to persons attending the hearings was the provision of a wide variety of housing types within communities. Morcover, seventy-five percent of the persons attending desired the encouragement of a wide varicty of commercial, cultural, and civic facilities in suburbia. NortheAstern Illinois Planninc Commission, 8 Planning in Northeastern Illinois 1-2 (March 1966). Sce also Tolan, Redevelopment-Irretrievable Opportunity for Variety, in THE NEW RENEwAL 22, 24 (Duggar ed. 1961). A typical large-scale project would include such types of housing as single-family detached homes, semi-attached row houses, high-rise cooperative apartments, and retirement housing.

10. In 1964, the average (mean) household size in husband and wife families where the head was under 45 years of age was 4.4. Of the nearly 21 million such familics, some 20 million were urban and rural non-farm residents; only 2.8 million had no children. U.S. Bureau of the Census, Statistical Abstract of the United States: 1965 39 (1965). The following chart illustrates home ownership of non-farm families by age groups.

\begin{tabular}{lcccc}
\hline $\begin{array}{l}\text { Age of } \\
\text { Household }\end{array}$ & Owning Homes & Renting Homes & Other & Total \\
\hline $18-24$ years & $15 \%$ & $60 \%$ & $25 \%$ & $100 \%$ \\
$25-34$ years & 47 & 45 & 8 & 100 \\
$35-44$ years & 71 & 26 & 3 & 100 \\
$45-54$ years & 72 & 24 & 4 & 100 \\
All non-farm Families & 61 & 32 & 7 & 100 \\
\hline
\end{tabular}

Source: 1965 FACT BooK 31.

Almost three of every four persons who are in the age group 35 to 54 years own their own homes. 1965 FACr BooK 31. For selected transactions insured by the FHA under section 203 for the year 1964, the average mortgagor was 33.2 years of age, enjoyed a monthly family income of $\$ 750.27$, had a $\$ 15,362,31.4$ year mortgage on a $\$ 16,216$ home of $1,206 \mathrm{sq}$. $\mathrm{ft}$. on a $\$ 3,130$ site with an average of 5.7 rooms of which 3.1 were bedrooms, $85.5 \%$ were 1 story structures, $61.5 \%$ had more than 1 bath, and $79.9 \%$ had a garage or carport. HHFA, 1964 ANNUAL REPort 123 (1965). 
schools and recreation than even the most aggressive local governments require through subdivision regulations. ${ }^{11}$ As he knows, homebuyers avoid tracts where their children must cross busy streets on the way to school. Community swimming pools and golf courses pay their own way in increased sales. But in small tracts there is usually no room to insert school and park sites, and insufficient housing units to write off their cost. As a result the entire community, instead of the development, bears the costs of its school and park facilities. ${ }^{12}$

There is no entirely satisfactory way of making the small, unplanned development pay for the expenses imposed on its neighbors. Some local governments have tried to ban all new development or, through minimum lot size zoning, to control population density. But the courts have been unsympathetic to these control measures ${ }^{13}$ and home builders

11. Cf. descriptions of Reston and Columbia, two recent new towns, in Weares. Dilemmas of Urban America $23-26$ (1965).

12. See, e.g., Heyman \& Gilhool, The Constitutionality of Imposing Increased Community Costs on New Suburban Residents Through Subdivision Exaclions, 73 YalE L.J. $1119,1119-22$ (1964).

There may be situations in which the burden of financing public facilities should fall upon existing residents of communities, despite the fact that newcomers create the need for additional facilities. Subdivision fees, like exclusionary zoning. an bar low income groups from suburbs. Why should suburbs be able to cast he burden of supplying public facilities for the less-well-off exclusively on the central cities in this way? When low density zoning forces a developer to concentrate on supplying high income housing markets against his better judgment about prevailing market trends, perhaps stringent limits on subdivision exactions-which are imposed in addi. tion to the high per-unit land cost created by exclusionary zoning-are justifiable. This question was latent in Midtown Properties, Inc. v. Town of Mfadison, 68 X.J. Super. 197, 172 A.2d 40 (1961), aff'd without opinion, 78 N.J. Super. 471, 189 A.2d 226 (App. Div. 1963). The developer, who owned $191 / 2$ miles of the 42 square mile township, contracted to donate schoolrooms and land for fire and police stations in return for zoning which would allow $75 \times 100$ lots, and some garden apartments, industry, and commer. cial uses. A later council revoked the contract, and the revocation was sustained. The court's opinion contained dicta that public service facilities could not be derived from subdividers but had to be financed out of public funds. Heyman and Gilhool expend considerable energy attacking this dicta. The facts of the Midtoun Properties case, though. suggest that large-scale developers can afford to dedicate land and to pay for public service facilities, but only if they can build for the heaviest markets, freed from the binds of local zoning ordinances. The case also implies that, depending on the strengths of respective housing markets, there are occasions when a large tract built for moderate income families is better able to absorb the costs of public facilities than onc constructed for high income groups. This is confirmed by a recent study of New York suburbs by the Pratt Institute School of Architecture which concluded that the ability of moderate income developments to support public facilities is generally greater than that of high income developments, N.Y. Times, Sept. 25, 1966, \$ 8, p. Rl, col. 3.

13. See, e.g., Christine Building Co. v. City of Troy, 367 Mich. 508, 116 N.W.2d 816 (1962) (invalidating a minimum lot size zoning ordinance which required building sites to be at least 21,780 square feet). But see Padover v. Township of Farmington. 374 
have powerful allies in the local landowners who hope to sell off their holdings. Communities resigned to rapid growth, and aware that they cannot force small-tract developers to dedicate lands for schools and parks, have imposed subdivision fees varying with the number of lots in a project. Increasingly, courts are willing to uphold such exactions only when the local government can prove that the additional community facilities for which the fees are assessed are uniquely attributable to the developer's project. ${ }^{14}$ Even in states where the courts allow the most liberal evidentiary standard for proving that a particular project has generated the need for a certain park or school, local governments rarely force small-tract developments to pay their own way in social services. ${ }^{15}$ Most of these expenses a large-tract builder bears without question.

Of course, the size of a project is no assurance of quality; huge developments may be poorly planned and niggardly in yielding space for public uses. But the guilty large builders usually share the characteristic small builder's plight of undercapitalization. Such a developer borrows heavily, at high interest rates-usually one per cent or more a month. ${ }^{16}$ His pressing loan repayment schedule is likely to prevent him from allotting planners and architects enough time to conceive and prepare careful plans, from experimenting with novel construction techniques, or from arranging land uses in unusual layouts for untested markets. ${ }^{17}$

Mich. 622, 132 N.W.2d 687 (1965) (divided court upholding a graduated lot-size ordinance which imposed acreage minimums ranging from 7200 to 20,000 square fet).

14. E.g., Pioneer Trust \& Savings Bank v. Village of Mt. Prospect, 22 Ill. 2d 875, 880, 176 N.E.2d 799, 802 (1961).

15. See e.g., Jordan v. Village of Menomonee Falls, 28 Wis. 2d 608, 621, 187 N.W.2d 442,449 (1965):

the approval of the instant and other subdivision plats . . . has required defendant village and the encompassing school districts to expend large sums for acquistion of park and school lands and construction of additional school facilities . . . made necessary by the influx of people into these subdivisions ... and . . . these ex. penditures are greater than the amount which has been exacted from the subdividers by way of land dedication and equalization fees paid in lieu of land dedication.

16. Interview With Robert Barclay, Barclay, Hollander \& Curci Co., Los Angeles, Calif., Aug. 4, 1966; Smith, The Low-Rise Speculative Aparturnt 48.61 (Institute of Urban and Regional Development, University of California, Berkeley, Resenrch Report 25, 1964); during the fourth quarter of 1965 state chartered savings associations in Callfornia reported yields on construction loans ranging from a minimum of $18.50 \%$ to a maximum of $16.80 \%$. State of California, Division of Savings and Loan, Department of Investment, Statistical Release No. 66-1, June 17, 1966, p. 3.

17. See, e.g., HERzOG, op. cit. supra note 2, at 22-24; Glikbarg, Financing Residential 
The competition of large, well-financed developers may eventually drive out small and undercapitalized builders. Each year more privately developed new towns and planned residential communities are buil $t^{18}$ while the number of small builders declines. ${ }^{10}$ Yet there are

Development, in California Land Securuty and Devecoparent 537-39 (California Practice Handbook No. 14, 1960).

18. New Towns for America, House and Home Magazine, Feb. 1964, p. 121; IWhere City Planners Come Down to Earth, Business Week, Aug. 20, 1966, p. 100.

19. According to the Bureau of Census, only $60 \%$ of all starts in 1964 of single-family non-farm residential structures were merchant built and intended for sale. The remaining 40\% were owner initiated or owner built. 1965 FACT Book 38-42. One authority estimated that, in 1949, builders of more than 100 houses a year accounted for about $24 \%$ of the total volume of housing starts. MAalser, Housenuildive IN Transtion 292 (1953). An NAHB survey estimated that the figure had climbed to 64\% by 1959 . NAHB, The Home Builder-What Does He Build?, Joumal of Homebuilding, Ararch, 1960, p. 26. A study of the building industry in Northern California registered $62 \%$ and $74 \%$ in 1959 and 1960. HERzoG, op. cit. supra note 2, at 21. During the first quarter of 1959, a study by the Bureau of Building Marketing Research revealed size of output as illustrated in the chart below:

Number and Per Cent of Butlders, By Size of Agtivity, Untted States, 1959

\begin{tabular}{|c|c|c|}
\hline Size & $\begin{array}{c}\text { Number of } \\
\text { Builders }\end{array}$ & $\begin{array}{c}\text { Per Cent } \\
\text { Distribution }\end{array}$ \\
\hline $\begin{array}{l}\text { 1. Small } \\
(1-5 \text { houses or under } \\
\$ 50,000)\end{array}$ & 156 & 19.4 \\
\hline $\begin{array}{l}2 . \\
(6-10 \text { houses or } \\
\$ 5,000-\$ 99,999)\end{array}$ & 137 & 17.0 \\
\hline $\begin{array}{l}\text { 3. Medium } \\
\text { (11-25 houses on } \\
\$ 10,000-\$ 99,999)\end{array}$ & 217 & 27.0 \\
\hline $\begin{array}{l}4 . \\
(26-75 \text { houses or } \\
\$ 300,000-\$ 999,999)\end{array}$ & 167 & 20.8 \\
\hline $\begin{array}{l}\text { 5. Large } \\
(76 \text { houses of } \\
\$ 1,000,000+)\end{array}$ & 103 & 12.8 \\
\hline 6. Unclassified & $\frac{24}{804}$ & $\frac{3.0}{100.0}$ \\
\hline
\end{tabular}

Bureau of Bulloing Marketing Research, Marketing and Researcil Panel, Ist. Repont (1959). The share of output of large builders as represented in the chart is somewhat larger than suggested by the U.S. Department of Labor reports, U.S. BuRenu OF Laeor Statistics, Dep't of Labor, Buli. No. 1170, Structure of the Residenthal Bulloivg INDUSTRY IN 1949 (1954); see also Mfeyerson, Terrett \& Whenton, Housinc, PEOple aNd CrrIEs 105-07 (1962). These sources are representative of virtually all recent studies of 
still few experienced real estate investors who possess the funds to develop large-scale projects. ${ }^{20}$ And loans in normal capital markets

output, and they are disappointingly consistent. The builder of 100 units typically produces two to four tracts of five to fifteen acres a year. Interview With John Malonc, Field Service Director, Homebuilders Association, Aug. 15, 1966. Herzog has summarized the situation:

[T] mains no more than a tendency. Even the changes which took place between 1950 and 1960 were not sufficient to remove the industry from the competitive (as opposed to the oligopolistic) class. In 1960, for example, the four largest northern California firms accounted for only about 11 per cent of the total houscbuilding in that area. The eight largest built only 22 per cent, and even the 20 largest could garner no more than 35 per cent of the market. Those percentages (concentration ratios) are well below those found in most other industrial sectors of the economy. Only in the service and distribution trades, and in about 15 per cent of the manufacturing industries (representing about 20 per cent of manufacturing output) can one find lower ratios.

HeRzoG, op. cit. supra note 2, at 27.

20. Constructing an experiment in urban or suburban environment, even on a limited scale, is costly. For example, San Ramon Village, a new community in Northern California, is a $\$ 250$ million, 4,500 acre development. One California association which participated heavily in development financing currently accounts a gross financing package of $\$ 45$ million. Letter From Patrick H. Price, Vice President, San Francisco Federal Savings and Loan Association, July 15, 1966. Even mixed use projects ordinarily require a minimum of 400-500 acres of land costing, typically, $\$ 5,000,000$. A developer with abundant financial backing would still have to invest between $\$ 1,000,000$ and $\$ 2,000,000$ of his own funds in such a venture. In Southern California there are fewer than thirty who could afford the price. Interview With Sid Carnine, Alscot Develop. ment Co., La Puente, Calif., Aug. 7, 1966. Urban renewal programs, public or private, are the most expensive of all. An example is Alcoa's Century City in Los Angeles which, partially completed, has cost $\$ 293$ million. See Where City Planners Come Down to Earth, supra note 18, at 102.

Real estate, a mainstay of the U.S. economy, especially in the post-war years, is perhaps the most neglected alternative among equity choices open to institutional investors [life insurance companies, pension funds, colleges and universitics]. Since 1945 the value of this nation's land has almost tripled, to around 360 billion, while the value of buildings has more than tripled. Yet, in spite of renl estate's substantial contribution to the national wealth, there is a reluctance on the part of many institutions to share in the rewards of real estate investment. Why do these intermediaries so often wear blinders when approaching this vigorous section of the economy? A number of explanations might be advanced. Certainly there is a paucity of information concerning the evaluation of return on real estate and the suitability of real estate as a component of institutional portfolios. On top of this there is the problem faced by many institutions of acquiring the investment techniques and the skills necessary in handling the web of regulatory authority restrictions surrounding largescale real estate transactions.

Ricks, REcent Trends In INSTITUTIONAL REAL Estate INVEstMent 1 (Institute of Urban and Regional Development, University of California, Berkeley, Research Report 23, 1964). Of the two barriers to real estate investment mentioned by Ricks, only one-legal rc. 
remain readily available for small and undercapitalized development. Thus undercapitalized builders working on small tracts are likely to remain an important element in the construction industry.

\section{Devices for Containing UnderGaptTALIZEd CONSTRUCtion}

Impatient with the pace at which new towns and planned communities are replacing small tracts, planners public and private have sought new means of shaping land development. They have lauded the English and Scandinavian new towns as superior efforts to realize the benefits of planning and development in large parcels. But Congress has shown little interest in similar direct government programs here."1 State laws could be written to require licenses and exorbitant bonds of land developers, in effect outlawing undercapitalized builders. The history of contractor licensing laws, however, suggests that the industry to be licensed tends to set licensing standards and dominate the administration of the laws, usually to preserve the status of existing licensees, discourage newcomers, and minimize price competition. ${ }^{22}$

traints-applies to savings associations, as association management is daily engaged in appraising real estate investment returns.

21. Among the most ambitious proposals was S. 1354 to provide federal aid for the purchase of remote tracts by state land development agencies which were then to lay out entire new cities, and sell the land to private developers subject to planning and use controls. S. 1354, 89th Cong., Ist Sess. § 604 (1965). Sce also, Goversor's Advisony Commission on Housing Problems, Report on Housinc in Calufornin 54 (1963). Its failure evidences Congressional reluctance to support direct government entry into the land development business. See Hearings on $S$. 1354 Before a Subcommittee of the Senate Committee on Banking and Currency, 89th Cong., Ist Sess. (1965). A similar rationale accounts for the defeat of H.R. 7500, a bill designed primarily to promote the orderly conversion of agricultural lands to suburban development through a pritate profit-making corporation which would be responsible for the acquisition of large tracts within five miles of existing urban centers and would eventually sell its holdings to developers. H.R. 7500, 89th Cong., 1st Sess. §§ 101-307 (1965). Sce Hearings on H.R. 7500 Before the Subcommittee on Conservation and Credit of the House Committee on Agriculture, 89th Cong., Ist Sess. 2-3 (1965). To date the only types of "planning and development" measures to achieve adoption are those which provide planning grants, see 68 Stat. 640 (1954), as amended, 40 U.S.C. $\S 461$ (a)-(I) (1964), as amended, 40 U.S.C. $\S 461$ (a), (b), (g) (Supp. I, 1965) or financing for utilities and similar traditionally public improvements to local governments, see Housing and Urban Development Act of 1965 § 701, 79 Stat. 489 (1965), 42 U.S.C. \$\$ 3101-08 (Supp. I, 1965), and which insure the mortgages of private developers for land acquisition and planning costs (Housing and Urban Development Act of 1965 \& 201(a), 79 Stat. 461 (1965), 12 U.S.C. $\S 174923-174911$ (Supp. I, 1965).

22. See Edwards, Legal Requirements that Building Contractors Bc Licensed, 12 LAw \& Contemp. Prob. 76 (1947); Comment, Mechanics Liens and Surety Bonds in the Building Trades, 68 YALE L.J. 138 (1958). Political and constitutional feasibility aside, the desir- 
There is no reason to expect a different result from the licensing of land developers. ${ }^{23}$ Subdivision regulations and zoning are ineffectual at substituting large projects for small. They encounter political and constitutional barriers, ${ }^{24}$ the public planners' view of the proper bounds of his authority, ${ }^{25}$ and the physical and economic limits of small sites. ${ }^{26}$

Although the federal mortgage insurance program probably has resulted in better suburban land development, ${ }^{27}$ the Federal Housing Administration (FHA) cannot by itself eliminate the blight of undercapitalized building. Since its inception the FHA has drafted model land use control legislation for local governments, imposed site and building design standards as prerequisites for insurance, and provided

ability of allowing only the well-capitalized to build houses is questionable. See notes 89 and 90 infra and accompanying text.

23. Subdividers must obtain licenses in some states but the major purpose of such laws is to discourage fraudulent land sales. See, e.g., CoLo. REv. STAT. ch. 118, art. 16 (1963).

24. See Heyman \& Gilhool, supra note 12, at 1122.

25. The planning fraternity is not committed to the theory that the public sector ought to dictate spatial arrangements. While many concur with Charles Haar that "The aim of planning may be to eliminate the inefficiencies of the market mechanism," few arc prcparcd to attempt to alter the basic structure of housebuilding. Haar, The Social Control of Urban Space, in CrtIEs AND SPACE 175, 200 (Wingo ed. 1963). Professor Dunham has rather aptly expressed the position for restraining the scope of planners' authority:

A refusal to approve a subdivision because the planners prefer a "Radburn" type of lay-out to that proposed by the private developer would be comparable to an order of the Federal Trade Commission preventing automobile companies from marketing a car with a two-tone color scheme because it believed the public would so quickly tire of the style that there would be accelerated obsolescence. In street planning terms, the plan commission ought to concern itself with design and lay-out of the subdivision only where the development as proposed will adversely affect neighboring properties.

Dunham, City Planning: An Analysis of the Content of the Master Plan, $1 \mathrm{~J}$. LAw \& EcoN. $170,185-86$ (1958). Even when planners seek affirmatively to shape the urban environment, the demands of time and the pragmatics of development force them to concentratc their limited resources in the large projects.

26. As the court in Jordan v. Village of Menomonee Falls, supra note 15, at 622, 197 N.W.2d at 449-50, explained:

Where a comparatively small tract of land is subdivided, ... and there is no adjoining land already devoted to school, park, or playground purposes to which a portion of the proposed subdivision might be attached, it usually would be impracticable to require dedication of any land of the subdivision. The two alternatives are either to relieve the subdivider from any obligation whatever in this direction, or to require payment of an equalization fee....

27. "As much as we malign the FHA they make even architects observe some stundards which the architects otherwise might not have observed. ... I think they've done a great deal to improve the standards for say the tract house." Demars, Using Routine Procedures to Create a Varied City in The New Renewal 41, 59 (Duggar ed. 1961). 
developers with planning advice.28 Until recently, however, mortgage insurance was available only in completed projects to homebuyers. To acquire land and plan the site the developer had to use funds which he did not recapture from FHA mortgage proceeds and down payments until after his houses were sold. Therefore, even with an FHA commitment to insure home mortgages, the undercapitalized builder needed to minimize site planning and land costs. In 1965 Congress extended insurance coverage to mortgages for land acquisition and site planning costs. ${ }^{29}$ The impact of this legislation will be limited, however, by the amount of insurance the FHA is willing to issue under the new program ${ }^{30}$ and its interest and discount rate ceilings. ${ }^{31}$ The maximum FHA rate is customarily lower than the going rate charged by savings associations, ${ }^{32}$ where small builders usually have to go for their front money. Of all mortgages written on new homes in the United States in 1964, only $22 \%$ were FHA insured; 33 and relatively few of these were obtained by small builders, ${ }^{34}$ who are deterred

28. See, e.g., HHFA, 1964 ANnual Report 123 (1965). An example of the FHA's role in shaping model zoning laws for local governments is described in Hanke, Planncd Cnit Development and Land Use Intensity, 114 U. PA. L. REv. 15 (1965) (discussing the FHA's Model Land Use Intensity Standards). However, the FHA has often supported and sometimes coerced monotonous uniformity in order to promote short-term savings in construction costs.

29. The FHA insures first mortgages (" 'first mortgage' includes such classes of liens as are commonly given to secure advances [including but not limited to advances during construction] on, or the unpaid purchase price of real estate . . . together with the credit instrument or instruments, if any, secured thereby . . . .") for land development ("land development' means the process of making, installing, or constructing improvements," but improvements "shall not include any building.") Housing and Urban Development Act of 1956 \$ 201(a), 79 Stat. 461 (1965), 12 U.S.C. 1749aa-174911 (Supp. I, 1965).

30. 30 Fed. Reg. 15035 (1965), 24 C.F.R. $\$ \S 1000.47-55$ (1966).

31. 30 Fed. Reg. $15034-35$ (1965), 12 C.F.R. $\S \S 1000.25, .35,50$ (1965).

32. The current FHA maximum rate is $58 / 4 \%$ plus $1 / 2 \%$ insurance premium while the going rate for long term financing in Southern California is $8 \%$.

33. HHFA, 1964 ANNUAL REPORT 74 (1965).

34.

VARIATIONS IN FHA-VA HousLng Starts for NORTHERN Calffornia and UNited States-1956.60

\begin{tabular}{lcccc}
\hline & $\begin{array}{c}\text { Northern } \\
\text { California } \\
\text { I-Family } \\
\text { Starts }\end{array}$ & $\begin{array}{c}\text { FHA Starts } \\
\text { in Northern } \\
\text { California } \\
\text { (Ist Inspection) }\end{array}$ & $\begin{array}{c}\text { VA Starts in } \\
\text { Northern } \\
\text { California } \\
\text { (Ist Inspection) }\end{array}$ & $\begin{array}{c}\text { Total FHA.VA } \\
\text { Starts in } \\
\text { Northern } \\
\text { California }\end{array}$ \\
\hline 1956 & 38,600 & 17,414 & 10,868 & 28,282 \\
1957 & 31,500 & 12,983 & 5,942 & 18,925 \\
1958 & 36,227 & 22,215 & 3,435 & 26,650 \\
1959 & 46,663 & 24,967 & 3,666 & 28,633 \\
1960 & 35,766 & 18,974 & 3,034 & 29,003 \\
\hline
\end{tabular}


by the costs of processing an FHA application, the discounts at which low interest FHA insured mortgages must be sold in tight money markets, and the reluctance of savings associations to write FHA insured loans. In 1964, for example, less than $5 \%$ of savings associations' mortgages were FHA insured. ${ }^{35}$ FHA programs tend, consequently, to be ineffectual at altering the development practices of small producers.

\section{The Present Role of Savings Assoclations in Land Development}

Developers depend on institutional lenders for most of their funds and only acquire land for which lenders are willing to supply construction loans. Yet rarely have those concerned with the quality of suburban land development attempted to restrain the undercapitalized builder by acting directly on his indispensable accomplice. ${ }^{30}$

\begin{tabular}{|c|c|c|c|c|}
\hline \multicolumn{5}{|c|}{ VARIATIONS IN FHA-VA HOUSING StARTS IN NORTHERN CALIFORNIA-1956-60 } \\
\hline & $\begin{array}{c}\text { Large-Scale } \\
\text { FHA-VA } \\
\text { Starts in } \\
\text { Northern } \\
\text { California }\end{array}$ & $\begin{array}{c}\text { Large-Scale } \\
\text { VA-FHA } \\
\text { as Per Cent } \\
\text { of Total } \\
\text { FHA-VA } \\
\text { Starts }\end{array}$ & $\begin{array}{c}\text { Percentage } \\
\text { Change in } \\
\text { VA-FHA } \\
\text { Starts from } \\
\text { Previous } \\
\text { Year in } \\
\text { Northern } \\
\text { California }\end{array}$ & $\begin{array}{c}\text { Percentage } \\
\text { Change in } \\
\text { Large-Scale } \\
\text { VA-FHA } \\
\text { Starts from } \\
\text { Previous } \\
\text { Year in } \\
\text { Northern } \\
\text { California }\end{array}$ \\
\hline 1956 & 25,202 & 89 & -38 & -18 \\
\hline 1957 & 19,555 & 103 & -33 & -28 \\
\hline 1958 & 23,632 & 87 & +41 & +21 \\
\hline 1959 & 24,303 & 85 & +8 & +8 \\
\hline 1960 & 21,619 & 98 & -23 & -11 \\
\hline
\end{tabular}

Source: HerzoG, op. cit. supra note 2 , at 44.

35. Cf. HerzoG, op. cit. supra note 2, at 40-46.

36. The problem has apparently been one of low visibility. The existence of the relationship other than for purposes of historical analysis has seldom even bcen acknowledged. See Colean, The Impact of Government on Real Estate Finance in Tue United STATES 75 (1950). Among the exceptions are presentations which appear regularly in trade publications advocating such practices as varied densities, open space, and so on. Norman Strunk, executive vice president of the United States Savings and Loan Leaguc, has explained that "In the main, I think our people regard our role as a financial intermediary and are probably not as significant in the decision as to the public use of land as they might well be." Letter From Norman Strunk, July 27, 1966. The League is attempting to inculcate awareness through such devices as the booklets on Land Planning (1962) and Design (1963) which appear in the United States SAvings \& LoAN League, Construgtion 
Of all the suppliers of capital for residential real estate in the United States, ${ }^{37}$ savings associations are the most important, ${ }^{38}$ holding $44.1 \%$

IENDING GUDE Among the other exceptions are a rather desultory reference in Goverion's Advisory Comm'n on Housing, Report on Housing in Calufornia appendix, at 328 (1963)) and Comment, The Savings and Loan Association Industry and Mfulti-Family "Home" Development, 38 So. GAL. L. REv. 594 (1965).

37. The following chart illustrates the total market shares of mortgage lenders in I-4 family non-farm homes, 1963 and 1964 .

Dollars are in billions (All Loans)

\begin{tabular}{|c|c|c|c|c|c|}
\hline \multirow[b]{2}{*}{ Type of Holder } & \multicolumn{2}{|c|}{1964} & \multicolumn{2}{|c|}{1963} & \multirow{2}{*}{$\begin{array}{l}\text { Net Increase } \\
\text { in } 1964\end{array}$} \\
\hline & Amount & Per Cent & Amount & Per Cent & \\
\hline $\begin{array}{l}\text { Saving and Loan } \\
\text { Association }\end{array}$ & $\$ 87.1$ & 44.1 & $\$ 79.4$ & 43.6 & 7.7 \\
\hline $\begin{array}{l}\text { Life Insurance } \\
\text { Companies }\end{array}$ & 28.7 & 14.5 & 27.3 & 15.0 & 1.4 \\
\hline Commercial Banks & 27.2 & 13.8 & 24.9 & 13.7 & 23 \\
\hline Mutual Savings Banks & 27.4 & 13.9 & 24.7 & 13.6 & 2.7 \\
\hline $\begin{array}{l}\text { Federal Credit } \\
\text { Agencies }\end{array}$ & 6.0 & 3.0 & 6.2 & 13.4 & $(-2)$ \\
\hline $\begin{array}{l}\text { State and Local } \\
\text { Government }\end{array}$ & 2.2 & I.I & 2.1 & 1.2 & .1 \\
\hline $\begin{array}{l}\text { Pension Funds, } \\
\text { Credit Unions }\end{array}$ & 1.6 & .8 & 1.2 & 0.7 & .4 \\
\hline Mortgage Companies & 3.3 & 1.7 & 3.0 & 1.6 & 3 \\
\hline Other Holders & 14.2 & 7.2 & 13.4 & 7.2 & .8 \\
\hline Total & 197.7 & 100 & 182.2 & 100 & 15.5 \\
\hline
\end{tabular}

Source: HHFA, 1964 ANNUAT REPORT 43 (1965).

38. See 1965 FACT Book 65 . Savings associations financed approximately 442,000 dwellings in 1964 or $29 \%$ of all housing starts. The proportion of private starts financed by associa. tions since 1955 has ranged between $25 \%$ and $31 \%$. As other institutional lenders are not required to segregate disbursements by purpose of losn, comparative figures are not available. The statistical series which reported the total volume of residential mortgage financing until the end of 1964 was compiled by the FHLBB's Operation Analysis Division. Omission of loans above $\$ 20,000$ was purportedly oftset by the inclusion of an approximately equal amount of loans on property other than residential mortgages. The following example for 1964 is the result of HHFA's correlation of FHLBB data with that of other federal agencies. 
of all non-farm residential mortgage debt. ${ }^{30}$ The associations provide about seven billion dollars annually for new construction, and about ten billion dollars for home purchase financing. Most of the industry's assets-about 130 billion dollars-are in real estate mortgages, more than $86 \%$ of which are on one- to four-unit structures. ${ }^{40}$

Savings and loan associations are bound by market forces and legal restraints ${ }^{41}$ to place their vast resources in mortgage loans for specula-

39. 1964 Loans-Number, Amount, Percentage, Distribution, and Tyie of Finanging of Non Fatm Mortgage Recordings of $\$ 20,000$ or LESS

\begin{tabular}{|c|c|c|c|c|c|}
\hline & \multicolumn{5}{|c|}{ Type of Mortgagee } \\
\hline & $\begin{array}{l}\text { Savings } \\
\text { \& Loan }\end{array}$ & $\begin{array}{l}\text { Insurance } \\
\text { Company }\end{array}$ & $\begin{array}{c}\text { Commercial } \\
\text { Bank }\end{array}$ & $\begin{array}{c}\text { Mutual } \\
\text { Savings } \\
\text { Bank }\end{array}$ & $\begin{array}{l}\text { Sub. } \\
\text { Total }\end{array}$ \\
\hline $\begin{array}{l}\text { Number } \\
\text { (in thousands) }\end{array}$ & 1450 & 109 & 739 & 193 & 632 \\
\hline $\begin{array}{l}\text { Amount } \\
\text { (in millions } \\
\text { of dollars) }\end{array}$ & 15759 & 1408 & 6656 & 2182 & 8528 \\
\hline $\begin{array}{l}\text { Number } \\
\text { (per cent) }\end{array}$ & 37 & 3 & 19 & 5 & 16 \\
\hline $\begin{array}{l}\text { Amount } \\
\text { (per cent) }\end{array}$ & 42 & 4 & 18 & 6 & 10 \\
\hline & & & & ype of Finan & \\
\hline & Misc. & Total & $\begin{array}{c}\text { FHA } \\
\text { Insured } \\
\text { Home } \\
\text { Loan }\end{array}$ & $\begin{array}{l}\text { V.A. } \\
\text { Guarantecd } \\
\text { Home } \\
\text { Loans }\end{array}$ & $\begin{array}{c}\text { Conven } \\
\text { tional } \\
\text { Loans }\end{array}$ \\
\hline $\begin{array}{l}\text { Number } \\
\text { (in thousands) }\end{array}$ & 770 & 3893 & 503 & 186 & 3204 \\
\hline $\begin{array}{l}\text { Amount } \\
\text { (in millions } \\
\text { of dollars) }\end{array}$ & 7388 & 36921 & 6573 & 2851 & 27497 \\
\hline $\begin{array}{l}\text { Number } \\
\text { (per cent) }\end{array}$ & 20 & 100 & 13 & 5 & 82 \\
\hline $\begin{array}{l}\text { Amount } \\
\text { (per cent) }\end{array}$ & 20 & 100 & 18 & 8 & 74 \\
\hline
\end{tabular}

SOurce: HHFA, 1964 ANNUAL REPORT 418-19 (1965).

40. United States Savings and Loan League, 1964 Savings and LoAn FAct Book 93.91 (1964). 1964 figures have been generally used in the study because complete data for that year is available from such sources as the FHLBB and the HHFA.

41. The controlling federal statute provides that federal associations shall lend on 
tive, undercapitalized enterprises. To compete with commercial banks for depositors, savings associations typically pay interest rates more than one-half per cent in excess of the commercial bank rate."2 They charge borrowers higher interest rates and make loans at greater loanto-value ratios. ${ }^{43}$ As a result, savings associations attract freshman

mortgages, primarily on residential real property of less than five units. Fome Owners" Loan Act of 1933 5(c), 48 Stat. 132 (1933), as amended, 12 U.S.C. $\S$ 1464(c) (1964), as amended 12 U.S.C. $\$ 1464$ (c) (Supp. I, 1965). The FHLBB further limits statutory investment powers through regulations such as 12 C.F.R. \$ 545.6.7 (1960), which pares down the statutorily permissible investment in multiple unit dwellings. Federal Savings and Loan Insurance Corporation (FSLIC) regulations add another dimension by requiring that no more than $10 \%$ of withdrawable accounts may be lent to a single borrower unless aggregate loans to that borrower are less than $\$ 100,000.28$ Fcd. Reg. 1629 (Fcb. 21, 1963), 12 G.F.R. § 563.9-3 (1966). The average association at the close of 1964 had assets of 19.1 million. 1965 FACT BOoK 87. Supplementing all of these restrictions is the Internal Revenue Code which limits the liberal bad debt deduction of associations if more than 36\% of assets are placed in other than specified investments-mostly residential development of less than five units. See note 80 infra.

42.

Average AnNual Yteed on Selected Types of Investarent 1930-1964

\begin{tabular}{|c|c|c|c|c|c|c|}
\hline Year & $\begin{array}{l}\text { Savings } \\
\text { Accounts } \\
\text { in } \\
\text { Savings \& } \\
\text { Loan } \\
\text { Assoc. }\end{array}$ & $\begin{array}{c}\text { Savings } \\
\text { Deposits } \\
\text { Mutual } \\
\text { Savings } \\
\text { Banks }\end{array}$ & $\begin{array}{c}\text { Time \& } \\
\text { Savings } \\
\text { Deposits } \\
\text { in } \\
\text { Commercial } \\
\text { Banks }\end{array}$ & $\begin{array}{l}\text { US. } \\
\text { Govt. } \\
\text { Bonds }\end{array}$ & $\begin{array}{l}\text { Slate \& } \\
\text { Loal } \\
\text { Bonds }\end{array}$ & $\begin{array}{l}\text { Corpo- } \\
\text { rate } \\
\text { Bonds }\end{array}$ \\
\hline 1930 & $5.3 \%$ & $4.5 \%$ & $3.9 \%$ & $3.3 \%$ & $4.1 \%$ & $4.5 \%$ \\
\hline 1935 & 3.1 & 2.7 & 2.6 & 2.7 & 3.4 & 3.6 \\
\hline 1940 & 3.3 & 2.0 & 1.3 & 2.2 & 2.5 & 2.8 \\
\hline 1945 & 2.5 & 1.7 & 0.8 & 2.4 & 1.7 & 25 \\
\hline 1950 & 2.5 & 1.9 & 0.9 & 2.3 & 2.0 & 2.6 \\
\hline 1955 & 2.9 & 2.6 & 1.4 & 2.8 & 2.6 & 3.1 \\
\hline 1960 & 3.86 & 3.47 & 2.56 & 4.01 & 3.69 & 4.41 \\
\hline 1964 & $4.19^{\circ}$ & 4.10 & 3.47 & 4.15 & 3.28 & 4.40 \\
\hline
\end{tabular}

Source: 1965 FACT BOOK 16.

- Estimated.

The opinion is widely held and thoroughly documented in the savings and loan industry that a spread of one-half of $I$ per cent between dividends paid by savings and loan associations and the savings rates paid by commercial banks is necessary to attract sufficient investment for savings and loan growth to keep pace with the demands of the mortgage markets. See United States Savings and LoAn Lengue, Savings aNd Loan ANwals 152-72 (1958); Hearings on The Treasury Department Report on Taxation of Mlutual Savings Banks and Savings and Loan Associations Before The House Committee on Ways and Means, 87 Cong., Ist Sess. 75 (1961).

43. Savings associations mortgages tend to be on more modest properties, have higher loan to value ratios, and cost more in interest and fees. In 1964 savings associations took legal or distress actions against $0.53 \%$ of their borrowers as compared with $0.46 \%$ for all 
builders unable to obtain funds from commercial banks or insurance companies. ${ }^{44}$ Ordinarily, they encounter an established developer only when he wants to retrieve the capital he has invested in a project. The larger developer who is a good credit risk generally obtains funding from banks and insurance companies even for his unconventional ventures. When he borrows from a savings association, he is usually seeking to recapture the capital he has invested in a completed project from mortgage proceeds-hardly the situation in which he considers the potential long term yield which sound planning might generate.

Since savings associations finance high risk ventures in exchange for high interest rates, they might also be expected to finance novel land developments as they sometimes do for small developers. ${ }^{46}$ But

lenders. 1965 FACr Book 77. A high percentage of these foreclosures are on short-term construction loans. See FHLBB, 1964 ANNUAL REPORT 11 (1965). The riskiness of construction loans is evidenced by high interest and fees. While we are unaware of any national figurcs on this subject, the statistical release published by the California Savings and Loan Commissioner indicates the true cost of money. For example, during the fourth quarter of 1965 state chartered associations in California enjoyed the following effective annual yields on new loans:

\begin{tabular}{|c|c|c|}
\hline \multicolumn{2}{|c|}{ Construction Loans } & \multirow{2}{*}{$\begin{array}{c}\text { Non-construction Loans } \\
\text { Effective Yield } \\
\text { (weighted average) }\end{array}$} \\
\hline $\begin{array}{c}\text { Maximum Yield } \\
\text { (weighted average) } \\
16.80\end{array}$ & $\begin{array}{c}\text { Minimum Yield } \\
\text { (weighted average) } \\
13.50\end{array}$ & \\
\hline
\end{tabular}

Source: State of California, Division of Savings and Loan, Department of Investment, Statistical Release No. 66-1, June 27, 1966, p. 3.

These figures probably do not reflect the national average, as California contract intercst rates have been $1 / 2$ to 2 points higher than in large eastern cities. Charges for commissions, premiums, and fees far exceed the national average. GOVFrNOR's ADVisORY COMM'N ON Housing Problems, op. cit. supra note 36, at 21. California statistics are particularly important; savings and loan assets in California are the largest in the nation-over $\$ 23$ billion. Illinois follows with $\$ 10,517,000,000$, Ohio with $\$ 9,144,000,000$ and New York with $\$ 7,370,000,000$. 1965 FACT BoOK 81 .

44. See note 2 supra.

45. An example is the Oakland developer of low-rise speculative apartment houses who decided to install light weight metal fireplaces. Commercial banks and insurance companies, uncertain of the market for such an amenity, denied him financing. He was compelled to pay the higher savings association rate for his first projects. The fireplitces were well received and the developer now obtains his loans from banks and insurance companies. The large developer who is a good credit risk ordinarily obtains funding from banks and insurance companies even for his unconventional ventures. When he borrows from a savings association, it is usually because he seeks liquidity, and liquidity is gencrally incompatible with experimental land development. The heavier the debt service costs, the less likely is a developer to experiment with new housing forms and to make long-tarm real estate investments. The Oakland apartment house developer is an exception; the builder who cannot obtain a favorable loan for his inventive enterprises usually modifies his plans to suit the conservative lender. Risse, The Influence of Institutional Lenders 
usually the risk is provided, not by a novel construction technique, but by the builder's low credit rating, the uncertainty of the housing market or a high loan-to-value ratio. Once a builder obtains a loan from a savings association, he faces heavy debt service costs which require a fast return on his investment. This is a further deterrent to experimentation.

Only infrequently do savings associations lend money for urban renewal projects ${ }^{46}$ and new towns or large planned communities. ${ }^{47}$ Such investments have traditionally required larger outlays than small associations can afford if they are to maintain portfolio diversity. This barrier is of decreasing importance because associations have been growing rapidly. Between 1954 and 1964, while the number of associations increased only slightly, their assets grew from $\$ 20,000$ 000,000 to $\$ 120,000,000,000.48$

The second reason that savings associations have not participated heavily in prime large-scale development is that mortgage yields are higher on speculative, conventional housing. ${ }^{40}$ But direct investors in predeveloped land, owners of commercial property such as shopping centers, and developers of large-scale planned communities have real-

upon Apartment House Development 18-20, 1965 (unpublished paper in the University of Southern California Law Library).

46. Interview With Russell C. Chase, President, Mfarina Federal Savings and Loan Association, Los Angeles, Calif., May 1I, 1966.

47. Home Savings and Loan Association, the largest state-chartered association in California, is a new town developer, thus exercising its statutory prerogative to invest in land development. New Towns for America, House and Home Magazinc, Feb., 1964, p. 121. Of the 75 new towns which should be completed by 1985 , only one appears to be sponsored by a savings association. Norman Strunk, Executive Vice-President, United States Savings and Loan League, suggests the reason: ". . . legal authority to invest major amounts in land is too limited to permit our business to be very active in the phase of community development." Letter, July 7, 1966. The need for additional funds for new town develop. ment is described in Hearings on S. 1354, supra note 21, at 44-45; Hearings on Proposed Housing Legislation for 1966 Before a Subcommittee of the Senate Committee on Banling and Currency, 89th Cong., 2d Sess. 11 (1966). See also, Los Angeles Times, Aug. 14, 1965, \$ J, p. 1, col. 1 .

48. United States Savings and Loan Lleague, 1955 Savings and Loan Fact Boor 39-40 (1955); 1965 FACr BooK 87. In 1954, there were 6,030 associations; in 1965, there were 6,248. $20.9 \%$ of all associations have assets under $\$ 1$ million; another $43.1 \%$ have assets under \$10 million. On the other hand, of the 6,248 associations operating in 1961, 1,011 had assets in excess of \$25 million. 1965 FACT Book 87.

49. Large sums in a single venture effect considerable savings for both lender and borrower. The conventional insurance company investor currently wants a $6.3 \% \%$ yield. Depending on the credit standing of the borrower, this can and often does result in rates as low as $6-1 / 4 \%$ on both construction and long term mortgages. Interview With Richard Chew, Manager of Mortgage Loan Department, Coldwell Banker \& Co., Los Angeles, Calif, Aug. 4, 1966. This is considerably lower than the average going savings and loan rate. 
ized greater returns than savings associations. ${ }^{50}$ If allowed to invest directly in land developments, savings associations would be likely to shift some of their funds from mortgages to reap these gains.

\section{LENDING RESTRICTIONS}

The public regulations which govern savings associations impose the concerns of the past on an industry ${ }^{51}$ whose finance needs and practices have changed radically. Savings associations were started during the industrial revolution as mutual aid societies by workmen who pooled their savings to provide one another with funds for building a home. ${ }^{52}$ These mutual aid origins account for peculiar rules that in some states give depositors the title of "stockholders"-although the association is in fact controlled by the owners of its publicly traded shares. ${ }^{53}$ New savers in federally chartered associations are surprised to learn that they are owners when they receive their first proxy form. Actually, control of federal associations is divided between management and federal regulators. ${ }^{54}$ This nominal mutuality has remained a part of the industry's public image and makes the proposal that associations become land developers seem radical indeed. But in practice savings associations are already professional lending companies, bear-

50. In the past decade, land in the United States has appreciated at the rate of $10 \%$ per annum. What about Real Estate as an Investment Now, U.S. News and World Rcport, June 20, 1966. In California, the average over a similar span has been $18 \%$ per annum. Interview With Kent Williams, Property Research, Los Angeles, Calif., July 5, 1966. Since 1956 , yields on successful shopping centers have ranged from 8 to $15 \%$. Intervicw with Walter Clark, Senior Loan Officer, Security First National Bank, Los Angeles, Calif., Aug. 14, 1966. There are no collected figures on returns on large-scale planned communities. However, a recent study by the NAHB indicates that the average builder receives $8 \%$ to $10 \%$. Interview With John Malone, supra note 19. With scale economies, this percentage tends to rise. HERzoG, op. cit. supra note 2, at 22-27.

51. The Federal Home Loan Bank (FHLB) and Federal Savings and Loan Insurance Corporation (FSLIC) were designed to inject needed money into the reeling mortgage market. See Hearings on S. 2959 Before a Subcommittee of the Senate Committee on Banking and Currency, 72d Cong., Ist Sess. 44.53 (1932). Its purposes, as specificd in the Fome Owner's Loan Act of 1933, are "to provide local mutual thrift institutions in which people may invest their funds and in order to provide for the financing of homes . . ." 48 Stat. 132 (1933), as amended, 12 U.S.C. § 1464(a) (1964).

In 1964, $76 \%$ of all associations, holding $96 \%$ of total industry assets, were insured by FSLIC. 1965 FACT BooK 122. Massachusetts, Ohio and Maryland provide insurance at the State level, $I d$. at $84-85.79 .8 \%$ of all associations holding $98.4 \%$ of all assets were members of the FHLB system. Id. at 111-12.

52. See, e.g., Hoagland \& Stone, Reat Estate Finance 192-96 (1965).

53. E.g., CAL. Frn. CODE $§ 5062$.

54. 1965 FACT Book 109-10. Associations with federal charters numbercd 1981, or $81.7 \%$ of all associations at the close of 1964. Their total resources then amounted to $\$ 61.6$ billion, or $51.7 \%$ of total assets of the savings and loan industry. $I d$. at 83 . 
ing scarce resemblance to groups of workmen in a pub sharing half crowns and ale.

Associations are required to place most of their assets in mortgages on single-family dwellings. This made sense in the 1930's when singlefamily homes, constructed by small builders, were the dominant pattern. At the time the average home builder was constructing fewer than four houses a year on single parcels or lots in small, unplanned subdivisions. ${ }^{55}$ Large-scale developments, on the other hand, were a hangover from the disastrous real estate boom. In the early years of the century there had been along mass transit routes scattered large-scale subdivisions which had been poorly designed; and in the 1920's and 1930's many had failed, leaving suburban communities with unredeemable expenditures for abandoned streets and utilities.50 It seemed only good sense for Congress to ignore the financing needs of the large development. Today, however, the big developer is responsible for most of what is imaginative and well-planned in residential housing, and the laws that divert savings association funds away from large developments make poor public policy.

Congress also worked on the assumption that no one but the association would advance home loans. Thirty years ago short term mortgages based on a $50 \%$ loan-to-value ratio seemed daring and ample, and commercial banks and other institutional lenders treated them as unsound high-risk investments.57 With increased job security for middle income wage earners, FHA mortgage insurance, and the Federal National Mortgage Association's (FNMA) secondary market operations, home loans have become acceptable risks for even the most conservative lenders. Today, commercial banks are making home and construction loans on terms that would have astounded the New Deal architects of the Federal Home Loan Bank (FHLB) system and the Federal Savings and Loan Insurance Corporation (FSLIC). ${ }^{\text {ts }}$

55. According to a Bureau of Labor Statistics study of 1938, the average builder of single family dwellings constructed only 3.5 houses a year. Only about one-fourth of the builders produced as many as the average. Of the twenty-eight cities in the BLS Survey with populations of 100,000 or more, thirteen did not have a builder who constructed twenty-five houses a year. Colean, American Housing, Prodlems and Prospects 75 (1944).

56. See, e.g., Cornick, Prearature Subdrision and Its Consequences 1.21 (1938).

57. See Hearings on S. 2959, supra note 51, at 29-32. See also Coleds, op. cit. supra note 36 , at $44-47,51-62$.

58. National Banks are currently permitted to make 25 year loans up $1080 \%$ of value provided that the principal is fully amortized during the term. 38 Stat. 273 (1913), as amended, 12 U.S.C. $\$ 371$ (1964), as amended, 12 U.S.C. $\$ 371$ (Supp. I, 1965). Amendments to the Banking Act enacted in 1935 as part of the effort to increase funds for mortgagelending permitted national banks to make 10 year loans up to $60 \%$ of value, provided 
Preempted in this market by other institutions and prevented by law from making substantial direct investments, the savings associations have had to make mortgage loans which approach the full value of the property. In the volatile real estate market savings associations are making home mortgage loans at $90 \%$ of value for 30 years, without the benefit of FHA mortgage insurance, and even in states where mortgage foreclosure costs may equal $10 \%$ of the value of the security.50 Developers large and small turn to savings associations when they seek to "cash out," i.e., to obtain a loan appraisal based on the fair market value of the completed project which exceeds actual costs, thus returning to the project sponsor his invested capital. ${ }^{60}$ Even with a $70 \%$ loan-to-value ratio, the savings association may have the only capital at risk in a speculative apartment house or tract.01 If the land values rise, the worth of the developer's equity increases, and he pays off the mortgage debt. When values decline, he defaults. In many states with substantial savings association activity, anti-deficiency judgment statutes bar mortgagees from recovering against debtors personally should the property bring a price at foreclosure inadequate to satisfy the debt. ${ }^{62}$ Thus while savings associations may suffer heavily in bad times, they profit only modestly from land inflation, despite the risks they take.

State and federal associations are allowed to make limited investments in real estate under a variety of laws. They are usually per-

that at least $40 \%$ of the loan was amortized during the term. Banking Act of 1935 , ch. 614, 49 Stat. 706-07 (1985).

59. Cf. Prather, A Realistic Approach to Foreclosure, 14 Bus. Law 132 (1958).

60. See, e.g., Sмiтr, op. cit. supra note 16, at 48-52, 59-62.

61. To say that savings associations are taking the risks which we ordinarily assign as "equity" risk is not to imply that apartment house or tract developers are receiving un. deserved gains. As Wallace F. Smith contends:

It has been customary to disguise the earnings of the real estate entrepreneur as a return on equity investment. If high loan ratios seem to indicate that mortgage lenders are providing equity capital as well, they do not mean that lenders are performing entrepreneurial functions. Our argument has been that the input of entrcpreneurship is a separate component of value and a necessary ingredient in a healthy real estate economy.

Id. at 95.

This is a compensable input and "it is the ultimate value of the package of resources, not their initial costs, which should govern long-term lending or investing decisions." Id. at 89. See also Hearings on H.R. 5840 Before the Subcommittee on Hotsing of the House Banking and Currency Committee, 89th Cong., 1st Sess. 413 (Statement of Arthur Padula, Builder). See also Elias \& Gillies, Some Observations on the Role of Speculators and Speculation in Land Development, 12 U.C.L.A. L. Rev. 789 (1965).

62. See, e.g., CAL. Crv. Proc. CODE \& 580(b); Hetland, Deficiency Judgment Limitations in California-A New Judicial Approach, 51 CatIF. L. Rev. 1 (1963). 
mitted to own the office buildings which they occupy, even if substantial space is leased to others. ${ }^{63}$ From state to state such acquisitions may not exceed fixed percentages of, variously, reserves, assets, surplus accounts, or paid-in savings liability. Everywhere associations are authorized to acquire, manage and develop foreclosed property for resale $^{64}$ But only thirteen states allow associations to purchase and develop land, ${ }^{65}$ and this investment prerogative is denied altogether to federally chartered institutions." Even in the thirteen permissive states land investment is limited to paltry percentages of an association's total assets. ${ }^{6 \tau}$

While federal associations lack the authority to invest in suburban land, they may place up to two per cent of their assets "in interests in real property located within urban renewal areas."cs But urban renewal equities have little attraction for federal associations. With enormous capital outlays the success of an urban renewal construction job depends on what happens to the buildings around it. Federal and state urban renewal procedures are time consuming, intricate, and often infuriating to the sponsor. Savings association management is unfamiliar with real estate values in typical renewal areas, and it is yet to be demonstrated that equity holdings in urban renewal projects are profitable. ${ }^{69}$ With the exception of urban renewal, savings associations have invested in real estate whenever possible. ${ }^{70}$

63. E.g., IrI REv. Stat. ch. 32, \& 799. See generally, Weels, Slalutory Investment Powers of State Savings Associations, 30 LEGAL BuLLEIIN 189, 202 (1964).

64. E.g., IrI. REv. Stat. ch. 32 § 792(g); Weeks, supra note 63, at 207.

65. See note 5 supra.

66. Interview With Orvil Fassett, Federal Home Loan Bank, Los Angeles, Cal., Aug. 8, 1966.

67. The California statute set out in the text at p. 15 is typial. The range seldom exceeds $10 \%$. See Weeks, supra note 63.

68. 48 Stat. 132 (1933), as amended, 12 U.S.C. 1464(c) (1964), as amended, 12 U.S.C. $\S 1464$ (c) (Supp. I, 1965).

69. Interview with Russell C. Chase, supra note 46. The same problems discouraged life insurance companies and New York mutual savings banks from investing in urban renewal equities after a few had entered the field. See Colens, Resewnig Our Crmes 91 . 94 (1953). Colean lists other reasons for the withdrawal of life insurance companies and mutual savings banks. Some local authorities, although not required by federal law, sought commitments prior to land assembly and clearance. "In effect, this made the investor the sponsor of the whole undertaking and subjected him to public criticism, interminable negotiations with local authorities, long delays, and the consequent loss of income on committed funds over what might be a period of several years." Id. at 92-93. See also ABRAMS, THE CITY Is THE FrontiER 95.98 (1965) (describing the difficulties of Metropolitan Life Insurance Company in developing Stuyvesant Town).

70. See, e.g., State of California, Division of Savings and Loan, Statistial Release No. 66-1, June 27, 1966, p. 12, which reports real estate owned by Californis associations pursuant to CAL. FIN. CODE $§ 6705$. As of March 31, 1966, such property was valued at nearly 
Construed liberally, existing law governing federal associations pro. vides a limited means for association sponsorship of land development. An association's assets may be invested "in the capital stock, obligations or other securities of any corporation organized under the laws of the State ... in which the home office of the association is located, if the entire capital stock of such corporation is available for purchase only by savings and loan associations of that State . . . but no association may make any investment under this sentence if its aggregate outstanding investment . . . would thereupon exceed 1 per centum of its assets. "'71 The Federal Home Loan Bank Board (FHLBB) has sought to limit the functions of such corporations:

Substantially all of the activities of such service corporation (shall) consist of originating, purchasing, selling and servicing loans upon real estate and participating interests therein, and/or clerical, bookkeeping, accounting, statistical, or similar functions performed primarily for savings and loan associations, plus such other activities as the Board may approve. ${ }^{72}$

The Board's regulations could be challenged as an unauthorized effort to restrict a right granted to associations by Congress. ${ }^{73}$ Or the Board's interpretation of its regulations might be protested on the grounds that the regulations are sufficiently broad to sanction land development activity. ${ }^{74}$ But a change in the regulations would be more expedient.

$\$ 240$ million. All associations eligible do not participate, particularly in current tight money conditions.

71. 48 Stat. 132 (1933), as amended, 78 Stat. 804-05, 12 U.S.C. $\$ 1464(c)$ (1964), as amended, 79 Stat. 465, 507, 12 U.S.C. § 1464 (c) (Supp. I, 1965).

72. 30 Fed. Reg. 11715 (1965), 12 C.F.R. \& 549.9-1(a) (4) (1966).

73. Since land development would ordinarily result in the creation of single family houses financed by savings association mortgages, an association's entrepreneurial cfforts could be regarded as an elaborate means of "originating loans," a permissible purpose for service corporations under the Board's present regulations.

74. Sentiment among many savings and loan men reflects this point of vicw. It is not wholly unwarranted. When Representative Addonizio of New Jersey introduced H.R. 8647 in 1961, its purpose was to provide for a situation particular to New Jerscy, although the bill was worded to apply to all savings and loan associations.

The Central Corporation of Savings and Loan Associations, a corporation wholly-owned by the State chartered savings and loan associations of New Jersey, had broad powers ancillary to the primary activities of the savings and loan business and operated as a very useful adjunct to the affairs of the co-owning institutions. For example, it could warehouse mortgages for them. Federal savings and loan associations activated in New Jersey could not participate in this cooperative organization as they were not empowered to invest their assets in capital stock. Letter From Hon. Wright Patman, August 2, 1966. As finally enacted, the bill disappointingly provided only the means of implementing cooperative data processing primarily for smaller associations. It has not been used 
Better still would be the enactment of an enabling law such as California Financial Code $\S 6705$, a typical state statute authorizing association land development:

An association may invest in real property and such investment may include subdividing and developing real property and building homes and other buildings on such property principally for residential use by veterans, housing for the elderly, or urban renewal or improvement. An association may own, rent, lease, manage, operate for income, or sell such property. Investments of an association under this section ... shall not at any one time aggregate more than whichever of the following is the lesser:

(a) Five percent of its total assets.

(b) An amount equal to the sum of its capital, surplus, undivided profits, loan reserve, federal insurance reserve, and such other reserves as the commissioner may prescribe. ${ }^{75}$

\section{The Risks of Savings Association's Becoming Land Developers}

A statute of this type, if adopted widely, would free savings and loan associations to become an important factor in the land development business. As a result there would probably be some improvement in the quality of new construction-at least to the extent that poor housing is attributable to the abundance of undercapitalized sponsors. For even with a five per cent limitation, association-developers would be spared the high financing costs and burdensome repayment schedules that drive many small developers to seek a quick and safe return in shoddy construction.

But savings associations are in business to make money, not to please architects. An association developer would be likely to contruct a new town only if returns on such a well-planned, large-scale development promised to exceed yields on poorly planned tracts, shopping centers or apartment houses. The California statute leaves this choice entirely to the developer's discretion. If an association found it more profitable to build housing without amenities, the statute would offer no reasons for the developer to provide them anyway.

Of course, the associations' powers could be confined to encourage the financing of high quality building. Larger, well-financed land development is ordinarily the best; therefore, lending authority might be limited to projects which exceed minimum acreages, densities, or costs. Exceptions might be necessary to permit the participation of

extensively. Nevertheless, the FHLBB limitations would seem in accord with Congres. sional intent. See S. REP. No. 1265, 88th Cong., 2d Sess. 55 (1964).

75. CAL. FIN. CODE § 6705 (Supp. 1966). 
small associations and to avoid prejudicing the associations against investment in urban cores and experimental projects of modest size. As an alternative, investment authority could be framed in qualitative terms, permitting only well-designed projects with diverse land uses and adequate open space for recreation and schools. If present supervisory agencies had to determine whether proposed investments satisfy the standard, financial supervisors, short on experience in planning, would be charged with functions beyond their competence. The task could be delegated to professional planners and architects.

Planning experts disagree, however, on the precise form which the city should take to realize the benefits of both urban diversity and rural amenity. Disciples of Frank Lloyd Wright, committed to open spaces and increased mobility, dispute the urbanisme of LeCorbusier's followers; and both groups are opposed by planners in the Garden City and English New Town tradition as well as by such enthusiasts of the traditional city as Jane Jacobs. Each of these positions contains splinter parties, purists and revisionists in endless variety. In sum, while the prologue, "freer access to natural amenities,"70 appeals to everyone, there is no consensus on how to go about improving the urban form. ${ }^{77}$ Because of these divisions, it probably makes sense to experiment with different types of urban arrangements and to provide housing consumers with the widest range of choices. ${ }^{78}$ The risk that experimentation might be impaired by a rigid, doctrinaire administration must be weighed against the prospect of undistinguished outputs if association investment is to be guided solely by consumer preferences. Should the question of planning controls stymie efforts to enact an enabling law, corporations restricted to one per cent of an association's assets and closely supervised by the FHLBB, could become land developing subsidiaries, empowered to conduct pilot projects. This would give the Board an opportunity to test numerous patterns of planning controls.

In markets with no backlog of demand for housing, savings associa-

76. Webber, Order in Diversity: Community Without Propinquity, in Crries AND SPACE 23, 54 (Wingo ed. 1963).

77. See, e.g., Goodman \& Goodman, Communitas 3-116 (2d rev. ed. 1960); Wurster, The Form and Structure of the Future Urban Complex, in Crries AND SPACE 78 (Wingo ed. 1963).

78. "It seems that only by maximizing the opportunities for free choice can an opti. mum balance be achieved. This requires, among other things, large-scale expcrimental residential developments to test different combinations of density, coverage, and design, since the average person's imagination is too limited to prefer something he has never seen." TUNnard \& Pushikarev, op. cit. supra note 1, at 70-71. 
tion competition might dislodge existing well-financed builders and developers. Membership in the FSLIC and FHLB programs provides associations with cheaper capital than land development companies can procure ${ }^{79}$ and associations are taxed at lower than corporate rates because of a favorable deduction for bad debt reserves. ${ }^{80}$ These advantages might permit savings associations to displace more efficient land developers.

But the supposed tax inequality between associations and land developers is an illusion. Associations' gains from land development are taxed at regular corporate rates; on that portion of their portfolio which is invested directly in real estate, their bad debts reserves are calculated in the same way as those of ordinary land development concerns.

79. The FHLB operates through twelve banks. They serve as central credit banks for member institutions and have no contact with the public other than through the sale of consolidated obligations. The maximum borrowing limit of any member is set at an amount not exceeding $50 \%$ of its total savings balances. Within this tolerance, a line of credit is established for each member institution. Interest rates to members vary with the length of the loan period and the state of the capital market. In 196t, they were as high as $4.5 \%$ and as low as $3.22 \%$ at various regional banks. Sec FHLBB, 1964 ANviul REPORT 104-05 (1965).

The FSLIC insures savings accounts of savings and loan associations up to $\$ 10,000$. In carrying out its function, the FSLIC may take over the assets of a defaulting institution, take over loans of a defaulting institution, or make direct loans to help rehabilitate. In. sured institutions pay a regular annual premium of $1 / 12$ of $1 \%$ of the total of all sarings and creditor obligations outstanding and certain reserve prep3yments. Sec FHLBB supra, at 30-42. While direct loans are infrequent, the fact of insurance increases depositor confidence and lowers the rate of dividends required to attract savings. See generally, 1965 FACr BOOK 109-25.

80. Savings associations may compute the bad debt deduction from taxable income by adding an amount determined to be a reasonable addition to the reserve for losses on nonqualifying loans (INT. REv. CODE of 1954, $\S 593(b)(I)(A)$ ), plus the reserve for qualified real property loans (defined in INT. REv. CoDE of 1954, $\$ 593$ (c)(1) as "any loan secured by an interest in real property which is to be improved out of the proceeds of the loan") which may be determined under one of the following three methods: (I) An amount determined by experience to be a reasonable reserve for losses; (2) an amount equal to the amount necessary to increase the reserve for losses to 3 per cent of qualifying real property loan outstanding at the close of the taxable jear; (3) an amount equal to 60 per cent of the taxable income for such year less the amount deducted for nonqualifying loans provided the difference does not exceed the amount necessary to increase the balance of reserve for losses for qualifying real property loans to 6 per cent of such loans outstanding at the close of the taxable year. INT. REv. CODE OF 1954, $\$$ 593(1)(2)-(4). However, the deduction is limited to the greater of the amount under method 1 or the amount of total bad debt deduction for qualifying and non-qualifying loans which equals the amount by which 12 per cent of total deposits at the close of the year exceeds the sum of surplus, undivided profits, and reserves at the beginning of the jear. INT. REv. CODE OF 1954, \& 593(b)(1)(B). See Hearings on the Treasury Department Report on Taxation of Mutual Savings Banks and Savings and Loan Associations, supra note 42, at 7-19. 
The associations derive their real competitive advantage from the FSLIC and FHLB programs. Conceivably, associations could be authorized to create land development companies funded entirely by uninsured public subscription. But unless funds were diverted from savings accounts, these corporations would have no appreciable effect on the availability of loans for undercapitalized building. Association management might convince potential savers to invest in development companies instead. If these companies failed, however, confidence in the industry would decline, thus creating some of the consequences the FSLIC was designed to prevent. Perhaps the best way to limit unfair competition is to follow the practice of some states and authorize a public administrator to withhold approval of any project which creates an excessive danger to existing development. ${ }^{81}$

Various calamities which might result from land development by savings associations can be imagined, but none of them seems very likely. Land prices might rise as savings associations bid for suburban and exurban land suitable for a subdivision. $A$ priori, it is just as likely that the entry of association developers will decrease land prices. Present prices are inflated by vendors who must take back mortgages or trust deeds for most of the purchase price. The magnitude of inflation is reflected in the appraisal practices of the Los Angeles County Tax Assessor; he assumes that for every dollar which the vendor finances, one dollar is added to the purchase price. ${ }^{82}$ Vendor financing is unnecessary when savings associations purchase.

Another fear is that association insiders will take illicit profits by selling their own land to the company at excessive prices. But management's existing power to issue mortgages based on their own appraisals offers as much opportunity for fraudulent self-dealing as the power to purchase real estate. In either case, the association can be protected by supervisory agents who make periodic reappraisals. ${ }^{83}$

81. E.g., Ill. Rev. Stat. ch. 32, § 792.7.

82. The Rule is not inflexible. For sound first mortgages with $30 \%$ down, the discount may be as low as $25 \%$; for second mortgages or subordinated purchase money mortgages with smaller equities, the discount may run as high as $80 \%$. Interview With Carl Lusk, appraisal office of the Los Angeles County Tax Assessor, Aug. 18, 1966.

83. The California Division of Savings and Loan currently engages in such a practicespot-checking approximately $5 \%$ of loans with reappraisals. A quantitative measure of the divergence between the Division's policy and the associations' policy may appear through such reappraisals, and may lead to a full evaluation of other potential divcrgencies. In one recent case, $15 \%$ of an association's net worth was frozen into xeserves on the basis of an audit of six months' lending. This, needless to say, is a potent deterrent. Interview With J. Walter Lautenberger, Jr., Senior Research Analyst, Calif. Div, of Savings and Loan, Los Angeles, Calif., July 8, 1966. 
If equity investment proves successful small builders who depend on savings associations for financing might lose their primary source of funds. To the extent that small builders act as developers, acquiring land and planning sites, they should be displaced by larger investors. Using vendor financing they pay more for land. Unlike large builders, they purchase sites at premiums within a year of development instead of three to five years earlier. ${ }^{84}$ They tend to buy smaller tracts, ${ }^{85}$ to the chagrin of rural vendors who prefer to sell entire tracts or farms; and, as noted at the outset, they plan sites improperly. But the activities of small builders as developers must be distinguished from their conduct as house builders. Marginal developers, who crowd houses together on small parcels and even then lose money on land acquisition, earn their profits by constructing houses. ${ }^{80}$ These builders could continue their construction activities within the context of large, planned communities. The prevailing practices of huge land devel-

84. Herzog, op. cit. supra note 2, at 25, 66-68.

85. There are no studies on the size tract which a small subdivider develops. The fact that they are small is evident from the economic size of the builders themselves. People conversant with the mechanics of development are in accord that the small develop small tracts and the large develop either large or small tracts. Interview With hent Williams, supra note 50. One may also resort to statistics on the average size of tracts. While densities vary with the topography and zoning, 3 to 5 houses per acre is probably accurate for Southern California. In 1968, 1964 and 1965, for example, the records of the Los Angcles County Engineer indicate that subdivisions (five units or morc) in the county and municipalities averaged $29.2,26.6$, and 26.2 units-or 5 to 8 acres each. Other sources feel that 30 acres is a more representative average. Interview With John Malone, supra note 19. The difficulty with such figures is that they do not establish the size of the builder or of his tracts- only that there are many small tracts. Similarly, construction loan figures might be employed to substantiate these assertions vividly, but they are not casily obtained and those available do not discriminate between loans on entire projects and loans on individual units. Many lenders record separate mortgages on each unit in a tract to protect themselves from unpaid mechanics. Interview With Walter Clark, supra note 50. Sce, c.g., CaI. Savings and LoAN COMMr'N, 1964 ANndal Report 28 (1965), wherein the following data appears:

CONSTRUCtion LOANS MAAE-1964

\begin{tabular}{lcccc}
\hline Purpose & $\begin{array}{c}\text { Number of } \\
\text { Loans }\end{array}$ & $\begin{array}{c}\text { Per Cent of } \\
\text { Total Loans }\end{array}$ & $\begin{array}{c}\text { Average } \\
\text { Amount }\end{array}$ & $\begin{array}{c}\text { Loan to } \\
\text { Value }\end{array}$ \\
\hline $\begin{array}{c}\text { Speculative } \\
\text { Construction }\end{array}$ & 30,443 & 20.3 & $\$ 34,952$ & 74.6 \\
$\begin{array}{c}\text { Construction } \\
\text { By Owner }\end{array}$ & 14,789 & 10.6 & $\$ 36,860$ & 70.8 \\
\hline
\end{tabular}

(Speculative construction is here used in the sense of any construction "for or by a borrower that he intends to see or dispose of upon completion of the construction.")

86. CE. Herzoc, op. cit. supra note 2, at $45-46$. 
opers are illustrated by the Irvine Company now developing 88,000 acres in Orange County, California, and Home Savings and Loan Association of California (assets over two billion dollars) with more than $\$ 44$ million in real estate other than association premises. ${ }^{87}$ These developers sell parcels in subdivisions marked for expensive housing to small builders, many of whom are the master craftsmen of the construction industry, specializing in custom houses. ${ }^{88}$ If large builders relied more on prefabrication or industrialized parts, they might be so much more efficient than small builders as to displace them even in luxury markets..$^{89}$ But housebuilders large and small tend to employ similar production techniques, and the concern which builds 100 houses per year is nearly as efficient as the largest firms. ${ }^{00}$

Some people fear that builders in a savings association project will be forced to obtain construction and "take out" financing exclusively from the land developing association. But state and federal anti-trust laws are available to police such arrangements. ${ }^{91}$

Another anxiety is that associations instead of charging excessive loan fees will lose vast sums if permitted to invest in undeveloped land. The limited available data suggest that undeveloped land does not deserve its notoriety as a risky investment. In the last decade land investment has yielded an $18 \%$ return with fewer foreclosures than

87. Cal. Savings and Loan Comm'N, op. cit. supra note 85, at 58.

88. Interview With Raymond Watson, Irving Co., Orange County, Calif, Aug. 6, 1966; Interview With Leonard Lockhardt, Manager, Mortgage Loan Dept., Home Savings and Loan Association, Los Angeles, Calif., July 7, 1966. This practice is also carried on in the construction of other new communities. See WEAvER, op. cit. supra note 11, at 23-24. Sec also Hearings on S.1354, supra note 21, at 397 ("By and large, in our industry, the small builders will buy from a land developer who is not a whole lot bigger, economically, than he is.").

89. The present prefabrication package may vary from 25 per cent to 90 per cent of the material comprising the house. Prefabricated housing accounts for less than one-tenth of all residential building, and the largest prefabricator in the United States produced only 30,000 dwellings in 1960. MEYERSON, TERRETT \& WhEATON, op. cil. supra note 19, at 113-16.

90. When the homebuilder reaches the 500-800 units per year output level, he experiences no further significant cconomies. MaISEL, op. cit. silpra note 19, at 221. On the other hand, most builders of over 100 units a year manage to some extent to accumulate sufficient reserves to inaugurate new and larger projects, ride out the fluctuations of the building cycles, fund their own land acquisition and development, and gencrally establish a forceful bargaining position vis-a-vis lenders, contractors, and suppliers. FIerzoc, op. cit. supra note 2 , at $22-27$.

91. Indeed, the whole parade of antitrust horribles-tying, exclusive dealing, market division, monopolization-are all possible under this scheme, but there is no reason to believe that their occurrence will be any more probable here than in the myriad of other savings and loan operations. 
conventional home mortgages. ${ }^{92}$ Were savings associations to become land developers, it would be appropriate to monitor their activity for its effects on land prices, large and small house builders, the quality of suburban land development, conflicts of interests, and anti-trust violations. But the chance of gains through better-financed land development outweighs the risks involved in experimenting.

Our conclusions are necessarily tentative due to a lack of supporting data on many crucial points. We do not know enough about the practices of savings associations to do more than surmise how management would react to increased investment powers; we are unable to predict their reactions with confidence. And, further, we can only guess at the ways in which institutional lenders do or could alter the processes of land development. The Federal Home Loan Bank Board has obtained $\$ 500,000$ to study the savings association industry with a view to improving its financial soundness. But we also need to design a system for depicting the complex relationships between the private land lenders and land planning. Perhaps there would be greater interest in such an endeavor if the Federal Home Loan Bank Board had remained within that network of agencies now incorporated in the Department of Housing and Urban Development. Short of a merger of finance and planning agencies, connections may be drawn between land finance institutions and planning goals through the exploration of specific hypotheses for law reform, such as we have sought to initiate here.

92. Interview With Russell C. Chase, supra note 46. A study in Southern California conducted by an independent agency on behalf of Property Research, Inc revealed that, proportionately, the ratio of raw land mortgage defaults to conventional mortgage defaults may be as high as 1 to 50. FHA mortgages on housing in the study area, for example, experienced a default rate of $1.9 \%$. In two counties within the area, Riverside and Ventura, on parcels of land of forty acres or more, default rates were $.028 \%$ and $.015 \%$, respectively. Interview With Kent Williams, supra note 50 . Long term mortgages, on the other hand, are eminently safer than construction mortgages. Interview With J. Walter Lautenberger, supra note 83. 